\title{
Kommentar
}

\section{Når nervesystemet påvirkes og hjertet stanser}

Greve-Isdahl og medarbeidere presenterer en sykehistorie som kan være en nyttig påminnelse. For det første kan tilsynelatende uskyldige symptomer hos små barn raskt utvikle seg i alvorlig retning. For det andre kan det minne oss på det vi prøver å innprente medisinstudenter og leger under spesialisering: Det er essensielt å kunne identifisere de barna som har alvorlig sykdom.

Ved innleggelsen var denne pasienten $i$ tilsynelatende god allmenntilstand. Med allmenntilstand mener vi hvordan barnet gir kontakt, kvalitet på skrik, respons på stimulering og omgivelser, hudfarge, hydreringstilstand og våkenhetsnivå. Innleggelsessymptomer med brekninger, heshet, kruppliknende stridor, slapphet og blekhet, men uten feber, bør reise mistanke om at dette er en sykehistorie som kan ta en alvorlig retning. To dager senere, da bevissthet og muskeltonus ble redusert, ga jenta dårlig kontakt. Da skal man uansett mistenke en alvorlig sykdom. Det var etter vår mening riktig å spinalpunktere denne jenta, men en forsømmelse at spinalvæsken ikke ble undersøkt adekvat. Vi er helt enig med forfatterne at dyspné kombinert med facialisparese trakk i retning av Guillain-Barrés syndrom i form av en akutt inflammatorisk demyeliniserende polyradikulonevropati (AIDP).

Hos barn er forekomsten av akutt inflammatorisk demyeliniserende polyradikulonevropati under halvparten av den for voksne (1). Spesielt er aldersgruppen under to år mindre hyppig i denne diagnosegruppen (2, $3)$. I over halvparten av tilfellene finner man forutgående luftveis- eller gastrointestinal infeksjon. Campylobacter er en hyppig forekommende mikrobe $(3,4)$.

Akutt respirasjonssvikt med en rask paralyseutvikling (Landrys paralyse) skjer ofte over dager, men kan også i sjeldne tilfeller gå over timer $(3,4)$. Hjertestans er en kjent, men heldigvis sjelden autonom komplikasjon hos barn og voksne. Behov for intensivmedisinsk kompetanse kan raskt oppstå. Pasientene bør derfor vurderes henvist til sentre som har erfaring med å håndtere komplikasjoner, og som ved behov kan gi respirasjonsstøtte i en elektiv og kontrollert prosess.

Det er verdt å merke seg de initiale symptomene med parestesier, gangvansker og lammelser hos større barn og voksne. Ved siden av den kliniske nevrologiske undersøkelsen er spinalvæskefunnene de mest karakteristiske ved diagnosen. Karakteristisk er også den nedsatte F-responsen ved nevrografi (5).
Man har ikke entydig konkludert i studier av behandlingen av barn, men det er et anerkjent prinsipp å starte med immunglobuliner $2 \mathrm{~g} / \mathrm{kg}$ fordelt over fem dager (6). Plasmaferese har vært forbeholdt pasienter med fortsatt progredigering. En viktig differensialdiagnose er transvers myelitt som krever en litt annen tilnærming, med steroider i høye doser initialt. Dette har ikke vist seg å være like effektivt ved akutt inflammatorisk demyeliniserende polyradikulonevropati Immunoglobulinbehandlingen kan forkorte forløpet, men har ingen sikker effekt på langtidsprognosen (7).

Denne jenta ble lagt på sengepost med et sentralt venekateter i lysken, og det ble påvist en bekkenvenetrombose det 17. innleggelsesdøgnet. Vi er ikke kjent med at det foreligger internasjonale retningslinjer for hvor lenge sentralt venekateter skal kunne bli liggende i lysken. Vår erfaring fra Barneintensivavdelingen ved Oslo universitetssykehus, Rikshospitalet, er at et sentralt venekateter i lysken gir langt raskere både infeksjoner og tromber enn et sentralt venekateter som er innlagt via vena jugularis interna eller vena subclavia. Hos oss praktiserer vi at et sentralt venekateter i lysken skal kunne bli liggende i inntil sju døgn. Samtidig måles og eventuelt gis antitrombin III (man tilstreber et antitrombinnivå på > 60-70\%), og kliniske tegn til venetrombose overvåkes.

I dette tilfellet ble sykehistorien ekstra dramatisk da barnet fikk ventrikkelflimmer. Hjertestans hos barn forårsakes i de fleste tilfellene av hypoksi, i motsetning til hos voksne hvor det oftest skyldes ventrikkelflimmer (8). Men også barn kan få ventrikkelflimmer. Bare de siste to ukene har vi ved vår avdeling resuscitert tre barn som følge av hjertestans. Det er derfor viktig at man er kjent med algoritmen for resuscitasjon av barn, og at man er trent på slike akuttsituasjoner, ikke bare hos voksne, men også hos barn.

\section{Jon Barlinn}

Barnenevrologisk seksjon

Kvinne- og barneklinikken

\section{Bjørn Aage Feet}

Avdeling for anestesiologi

Akuttklinikken

\section{Ola Didrik Saugstad}

odsaugstad@rr-research.no

Pediatrisk forskningsinstitutt

Oslo universitetssykehus
Jon Barlinn (f. 1961) er barnelege med spesialkompetanse i barnenevrologi og seksjonsleder ved Barnenevrologisk seksjon, Oslo universitetssykehus, Ullevål og Rikshospitalet. Ingen oppgitte interessekonflikter.

Bjørn Aage Feet (f. 1961) er spesialist i anestesi med spesialkompetanse i barneanestesi.

Dr.med. fra 1998 og MBA fra 2010. Han er seksjonsleder og overlege ved Avdeling for anestesiologi, Akuttklinikken, Oslo universitetssykehus. Ingen oppgitte interessekonflikter.

Ola Didrik Saugstad (f. 1947) er dr.med., professor 1 i barnesykdommer ved Universitetet i Oslo og leder av Pediatrisk forskningsinstitutt, Oslo universitetssykehus.

Oppgitte interessekonflikter: Forfatteren har mottatt honorar for ekspertvitnesbyrd i tingrettssaker og for rådgivning fra Norsk Pasientskadeerstatning.

Litteratur

1. Hahn AF. Guillain-Barré syndrome. Lancet 1998; 352: 635-41.

2. Rantala H, Uhari M, Niemelä M. Occurrence, clinical manifestations, and prognosis of GuillainBarré syndrome. Arch Dis Child 1991; 66: 706-8, discussion 708-9

3. Olivé JM, Castillo C, Castro RG et al. Epidemiologic study of Guillain-Barré syndrome in children < 15 years of age in Latin America. J Infect Dis 1997; 175 (suppl 1): S160-4

4. Korinthenberg R, Schessl J, Kirschner J. Clinical presentation and course of childhood GuillainBarré syndrome: a prospective multicentre study. Neuropediatrics 2007; 38: $10-7$

5. Gordon PH, Wilbourn AJ. Early electrodiagnostic findings in Guillain-Barré syndrome. Arch Neurol 2001: 58: 913-7.

6. Hughes RA, Swan AV, Raphaël JC et al. Immunotherapy for Guillain-Barré syndrome: a systematic review. Brain 2007; 130: 2245-57.

7. Hughes RA. Ineffectiveness of high-dose intravenous methylprednisolone in Guillain-Barré syndrome. Lancet 1991; 338: 1142.

8. de Caen AR, Kleinman ME, Chameides L et al. Part 10: Paediatric basic and advanced life support: 2010 International consensus on cardiopulmonary. resuscitation and emergency cardiovascular care science with treatment recommendations. Resuscitation 2010; 81 (suppl 1): e213-59.

Mottatt 21.11.2011, første revisjon innsendt 19.12.2011, godkjent 21.12.2011. Medisinsk redaktør Are Brean. 